\title{
Dynamic Capabilities for SME Participation in Public Procurement
}

\author{
Temidayo 0. Akenroye \\ Liverpool Business School, Liverpool John Moores University, Liverpool, UK \\ Jonathan D. Owens \\ Salford Business School, University of Salford, Manchester, UK \\ Jamal Elbaz \\ Department of Management, Ibn Zohr University, Agadir, Morocco, and \\ Olatunde A. Durowoju \\ Liverpool Business School, Liverpool John Moores University, Liverpool, UK
}

\begin{abstract}
Purpose: Although small and medium-sized enterprises (SMEs) play major roles in most economies in terms of job creation, innovation and contribution to national income, they are often underrepresented in public procurement markets. This paper explores how dynamic capabilities theory can improve SME participation in public procurement.
\end{abstract}

Design/Methodology/Approach: Through a systematic literature review, the paper identifies common barriers to the effective participation of SMEs in public procurement and explores the applicability of dynamic capabilities theory in addressing these barriers.

Findings: A theoretical analysis was conducted in order to identify possible relationships between the factors reported in the literature as barriers to SME participation in public procurement and different components of the dynamic capabilities of firms (i.e. sensing, seizing, reconfiguring and learning). Seven key propositions were generated to guide future research.

Practical implications: The paper contributes to the ongoing debate about whether and how SMEs can leverage their resources and capabilities to develop self-help strategies to improve participation in public procurement, an area yet underexplored in the literature.

Originality/Value: This is one of the few studies examining the implications of firm-level capabilities of SME activity in public procurement markets. The findings may be beneficial to SME managers/owners, particularly regarding firms' ability to leverage resources and capabilities to participate effectively in public procurement.

Keywords: Dynamic capabilities, Resource-based theory, SMEs, Public sector procurement 


\section{Introduction}

Although small and medium-sized enterprises (SMEs) are vital actors in enhancing national economic growth and development, they are very often underrepresented in public sector markets. Policymakers and scholars have attempted to address this issue, such as by examining the barriers facing SMEs in public sector markets (Glover, 2008; Uyarra et al., 2014; Loader, 2013; Pickernell et al., 2011) and analysing measures and policy actions employed by governments to support SME participation in public procurement (Flynn and Davis, 2015; Loader, 2018). However, scholars have paid little attention to the ability of small businesses to develop self-help strategies for creating competitive advantage in public sector markets (e.g. Loader, 2013; Pickernell et al., 2013).

Previous studies in this area draw on market orientation, entrepreneurial orientation (Reijonen, Tammi and Saastamoinen, 2016; Tammi, Reijonen and Saastamoinen, 2014) and relational capability (Flynn and Davis, 2016). However, ways in which SMEs can develop dynamic capabilities to improve activity in public procurement markets have so far been under-researched in scholarship. There are at least two possible reasons for the paucity of evidence. Firstly, SMEs are presumed to be incapable of competing with larger firms on the same terms (Kreiser et al., 2013) with respect to both size and resources. The second is that the public sector often discourages researchers from engaging their suppliers as research participants (Flynn and Davis, 2016b), which in turn can affect the ability to recruit SME suppliers in this market. Concepts and theories from the broader RBV literature can nevertheless help explain how SMEs can exploit internal resources and capabilities to address the barriers faced in the public sector markets. This paper addresses this gap in research.

According to Pisano (2017), the research agenda in this area should be reorganised around the fundamental strategic challenges/barriers facing firms in discovering and choosing capabilities that initiate competitive advantage. Consequently, this paper will examine the following research questions:

- RQ1. What are common barriers to effective participation of SMEs in public procurement markets?

- $R Q 2$. How can the SMEs build and deploy dynamic capabilities to improve participation in public procurement?

To address these questions, the paper presents an overview of the dynamic capability theory and discusses the implications for SMEs to improve participation in public procurement. It conducts a 
systematic review of the literature to identify and analyse the common barriers facing SMEs in public procurement markets. Next, it presents a theoretical analysis of how dynamic capabilities can help an SME to address these barriers, resulting in seven propositions. The paper contributes to the SME-public procurement nexus in a unique way. It seeks to advance theory development by creating a model that can be used for evaluating the application of DC as the resource-based view of SMEs in the procurement process. This can increase understanding of the role of internal resources and capabilities in enhancing SME participation in public procurement. Centrally, therefore, this paper argues that any debate on SME business competitiveness or success is deficient should it lack consideration of internal firm factors which can help them to access and compete for contract opportunities effectively in the public sector.

\subsection{SME - Public Procurement Nexus: An overview}

The nexus between SMEs and public procurement is gradually becoming a topical issue in academic and policy circles. This is due to the potential contributions that SMEs can make to a country's economy and the multiplier effects on job creation, improvement of living standards and provision of goods and services (Etuk, Etuk, and Michael, 2014; Ensari and Karabay, 2014). SMEs are considered the drivers of innovation in most industries (Madrid-Guijarro et al., 2014), and the government stands to benefit from engaging with them to address some of the complex challenges facing public services. Furthermore, by engaging SMEs, public organisations can increase supplier diversity and bring more innovation through procurement (Simionescu and Bica, 2014).

Existing research also acknowledges the importance of public sector contracts to small businesses. Medina-Arnáiz (2010) argues that SMEs can target the public-sector markets for demand stability and as a source of predictable income. However, the opportunities that public-sector markets present to SMEs may be unsustainable because procuring organisations are constrained by limited financial resources due to austerity and budgetary cuts (Citroni, Lippi and Profeti, 2019; Institute for Fiscal Studies, 2015). It would therefore be illogical for SMEs to rely on public sector markets as their sole source of revenue. They may need to explore opportunities in other markets (e.g. supplying private firms) to earn extra income and secure a continuous stream of revenue.

Furthermore, SMEs have the unique advantage of agility, flexibility and ability to offer customised services (Hillemane, 2012), which can be a source of competitive advantage when bidding for public sector contracts. However, despite their significant contribution to economic development, rates of participation and success in winning public contracts are significantly lower for SMEs than their larger counterparts (Davis and Brady, 2014). While previous studies have addressed the barriers facing SMEs in public procurement, they focus more on how government can lower these barriers and boost participation (e.g. Loader and Norton, 2015; Loader, 2015; Flynn and Davis, 2015; McKevitt and Davis, 2015). This paper offers an alternative perspective on this debate by exploring how to address the problem of SME underrepresentation in public procurement markets from the firm dynamic capabilities approach. The section below discusses the key components of the theory of dynamic capabilities and its implications for improving SME participation in public procurement.

\subsection{Dynamic Capability (DC) theory: Development and critique}

The concept of DC was derived from the resource-based view to explain how organisations can deploy internal resources and capabilities to gain a competitive advantage in a dynamic business environment. It has been defined as the "firm's ability to integrate, build, and reconfigure internal

(C)Akenroye, T; Owens J D; Elbaz; J and Durowoju, O A.

British Process Management Journal: DOI 10.1108/BPMJ-10-2019-0447 
and external competencies to address rapidly changing environments" (Teece, Pisano and Shuen, 1997, p. 516). Since the term was introduced by Teece, the theory has been extended by Eisenhardt and Martin (2000) to include strategic routines and repetitive actions through which firms realise new resource configurations as markets change, develop and expire. Other proponents of DC agree with Teece's view, but emphasise the importance of configuration, strategic alignment, networking and knowledge transfer in helping firms to create a new bundle of resources or transform existing capabilities (e.g. Helfat et al., 2007; Zahra, Sapienza, and Davidsson, 2006; Borch and Madsen, 2007; Ambrosini and Bowman, 2009).

Nevertheless, Teece $(2016,2018)$ made a major contribution towards the development of this specific theory by disaggregating dynamic capabilities into three key micro-foundations: (1) sensing, which helps an organisation gather and evaluate market information to understand competitors and customers' needs; (2) seizing, which provokes the development of new products or services to help exploit sensed opportunities (Wagner et al., 2017); and (3) reconfiguring, which involves the ability to maintain competitiveness through enhancing, combining and transforming the firm's internal and external resources/assets (Teece, 2012). While these elements of DC have been widely used in management research (e.g. Pisano, 2017; Sprafke, Externbrink and Wilkens, 2012; Burisch and Wohlgemuth, 2016), the implications for improving SME participation in public procurement is still an underexplored area in the literature. This paper seeks to advance knowledge in this area.

Other scholars have added new insights from the field of organisational learning to extend DC theory (e.g. Hotto et al., 2015; Pedler and Burgoyne, 2017; Easterby-Smith et al., 2006). This brings to the fore the concept of Learning Orientation (LO), which serves as a source of the dynamic capabilities of a firm (e.g. Yung-Chul, 2013; He et al., 2018). LO contends that a firm can gain competitive advantage in the marketplace by demonstrating a strong commitment to learning, openmindedness, and a shared vision (Beyene et al., 2016; Sinkula, Baker and Noordewier, 1997; Calantone et al., 2002). These elements of LO could be important for the development of dynamic capabilities in SMEs seeking to improve participation in public procurement. For example, commitment to learning can prompt SMEs lacking public tendering experience to undertake a relevant training course.

Table 1 shows a summary of the key elements of a firm's dynamic capabilities cited in the literature. This paper argues that, through these capabilities, firms (particularly SMEs) can integrate and reconfigure resources in preparing for and responding to challenges in public sector markets, which have become increasingly competitive (Graells, 2015) and dynamic (Dawoody, 2012; Leontitsis and Ladi, S, 2018) due to the non-linear and unpredictable nature of public policies. For example, there are various barriers facing SMEs in public procurement, such as prejudice and discrimination based on size, resource constraints, and experience (as previously discussed). These are the riskier challenges facing organisations because managers cannot easily predict them (Mason, 2007). Hence, subsequent sections will be dedicated to exploring the applicability of the concept of dynamic capabilities to barriers facing SMEs in public procurement.

Table 1 (file is attached)

Although DC has become one of the most important theoretical approaches in business and management research (Schilke et al., 2018), it has several shortcomings. The concept has been

(CAkenroye, T; Owens J D; Elbaz; J and Durowoju, O A.

British Process Management Journal: DOI 10.1108/BPMJ-10-2019-0447 
criticised as ill-defined (Ambrosini \& Bowman, 2009), one such example being the lack of clear models to understand the constituent concepts, the nature of the capabilities (Zott, 2003) and how they operate to affect competitive advantage (Schreyögg \& Kliesch-Eberl, 2007). While the various debates on DC concepts seem complementary, they do not share a common theoretical foundation (Peteraf et al., 2013; Burisch and Wohlgemuth, 2016). These critics seem only to frown at theoretical pluralism around DC, without paying attention to contextual factors that could influence its practical application.

In fact, DC may have a negative effect on the performance of firms that operate in static environments (Drnevich and Kriauciunas, 2011), and might not necessarily guarantee the desired competitive advantage (Winter, 2003) as the only strategic option available for firms in dynamic environments. Likewise, in a paper titled "Blind spots of dynamic capabilities: A systems-theoretic perspective", Burisch and Wohlgemuth (2016) use systems theory to examine key weaknesses of DC. They posit that it might be difficult for organisations to fully achieve flexible capabilities and adapt to environments they cannot fully comprehend, given the ever-changing environment in which businesses operate. This relates to another criticism that the hypothesised relationship between DC and competitive advantage is inconsistent (Pezeshkan et al., 2016). Regardless of such criticism, however, scant attention has been paid to the implications for SME participation in public procurement. To examine the role of DC in this, it is important first to identify common barriers or challenges to SMEs effectively participation in public tender. This requires a systematic review of extant literature to identify the common barriers, conducted in the next section.

\section{Methodology for Systematic Literature Review}

Searches for published articles were conducted using the three most common databases in business and management studies (Klang, Wallnöfer, \& Hacklin, 2014; Maier, Meyer and Steinbereithner, 2016): Emerald Journals, ProQuest and Scopus. The initial search process encompasses the main topic of the study, using terms 'SMEs' OR 'Public procurement'. Given the multidimensional nature of the research topic (i.e. SME and public sector procurement), the review process encompasses studies published in academic journals and research produced by government and policymakers. Although some scholars (e.g. Loon, Otaye-Ebede and Stewart, 2019; Podsakoff, Mackenzie, Bacharach, and Podsakoff, 2005) have argued that selecting only journal articles would signify validated knowledge, such restriction can potentially skew evidence and make the focus of a review process too narrow (MacLure, 2005; Dixon-Woods et al., 2006). Searches continued progressively within each return set in the databases using the Boolean terms 'Barriers' OR 'Obstacles' then 'SME access*' and 'tender*ing weaknesses'. Wildcards were also used to widen the search.

Figure 1 shows the steps taken in the literature search, the screening and selection process. The articles were screened for relevance and aptness to addressing the study's objective. For example, articles were excluded for the following reasons: i) themes involved investigating procurement practices of SMEs; ii) a focus on procurement activities within private sectors; iii) articles focused on success factors of SMEs' supply chain practices; and iv) articles highlighted related concepts e.g. SME-friendly procurement policies, but with no reference to barriers or challenges of small suppliers. Furthermore, the inbuilt filters in the databases were used to exclude articles, books and case studies published earlier than the last decade and restrict the articles to those published in English. The articles emerging from the process were merged: Emerald had 105 returns, while

(CAkenroye, T; Owens J D; Elbaz; J and Durowoju, O A.

British Process Management Journal: DOI 10.1108/BPMJ-10-2019-0447 
ProQuest and Scopus recorded 51 and 73 respectively. After removing duplicates from the merged set, abstracts were reviewed to determine further eligibility and relevance of articles. The final number of articles used in the analysis was 33 .

Figure 1. (file attached)

\subsection{Data abstraction, coding and synthesis}

Cho and Egan (2009) and Garrard (2007) recommend the use of a classification table when analysing articles emerging from systematic review to aid initial data abstraction. This approach was adopted to develop a classification matrix that categorises the thirty three papers according to the following subtitles: author name(s), publication year, study aim, method (data collection approach, analytic methods), study location and summary of findings (see Appendix Table 1). The classification matrix made data analysis structured and orderly to reduce bias and human error. The full text of each article was read carefully to enable inductive coding and synthesis of themes relating to the barriers facing SMEs in public procurement. The themes were further categorised into broader groups of barriers to aid discussion of findings.

\section{Results}

\subsection{Geographical location}

As shown in Table 2, most research on SME barriers to public procurement was conducted in countries within the European Union, particularly the United Kingdom. The fact that the UK government, over the last decade, actively and consistently pursued various policy measures to improve SME access to public sector contracts (Loader, 2017) could have increased academic interest in this field.

Table 2. (file attached)

\subsection{Journals categories}

As shown in Table 3, the main categories of journals in which the articles were published are in relation to public administration, small businesses, entrepreneurship, politics and supply chain management. This suggests that interdisciplinarity has improved scholarly understanding of the barriers facing SMEs in public procurement. There is however a need to integrate more effectively the concept of SME involvement in public procurement in academic debate. Looking at the number of non-peer reviewed academic articles (i.e. study reports, government inquiry reports and policy documents), research in this field of study has not developed much into academic publications.

Table 3. (file attached)

\subsection{Classification of the articles according to research methodology}

Table 4 shows the distribution of the research methodologies in the selected articles. These can be classified into six groups: case study, document analysis, survey, interviews, literature review and mixed methods. Some of the articles (12 out of 33) use survey methodology to examine barriers to SME participation in public procurement. Others (9 out of 33 articles) leverage secondary data to examine different areas of study within the field. There is scope for using qualitative methodologies 
such as interviews and case studies to ask more in-depth questions and provide a broad perspective on the dimensions and impact of barriers to SME participation.

Table 4. (file attached)

\subsection{Findings about barriers to SME participation in public procurement}

The articles on this subject have focused on various themes. Loader (2013) has previously classified barriers into three groups: factors imposed by the public-sector environment, the public procurement process and SME resource limitations. This classification method was adopted to provide a much broader categorisation of barriers as external and internal factors causing SMEs to be underrepresented in public sector markets (see figure 2). For example, what Loader regarded as factors imposed by the public-sector environment and the public procurement process would correspond to external factors. Similarly, barriers imposed by SME resource limitations, as conceptualised by Loader, would correspond to internal factors.

Figure 2. (file attached)

\subsubsection{External factors}

The external factors can be broken down into two types: barriers originating from the workings of the public-sector environment and those related to the procurement process (Loader, 2013). One such barrier is the conflicting priorities of cost savings and support for small businesses. When faced with similar trade-off decisions, public organisations often lack direction in where efforts should be focused to reduce SME underrepresentation (Ancarani et al., 2019; Suliantoro, Winarno and Handayani, 2019; Loader, 2011). The likelihood is that contracts will be awarded to large suppliers given their ability to produce more cheaply (through economies of scale) than SMEs (Nicholas and Fruhmann, 2014).

Furthermore, public buyers lack adequate skills to make the contracting process more attractive to SMEs (Georghiou et al., 2014; OECD, 2013) and often prefer to do business with well-established larger companies (Loader, 2015). As Pickernell et al., (2013) underline, larger companies are more likely to access public sector contracts than SMEs that are fresh in the market. Similarly, previous research (Loader, 2011; Ward and Rhodes, 2014;) suggests that public procurers perceive a risk in contracting with SMEs, given resource constraints, inadequate human capital and financial (in)security. These embedded organisational cultures are examples of external barriers imposed by the public sector environment which are outside the scope of influence/control of SMEs seeking to participate in public procurement.

As seen in figure 1, the public procurement process can also present external barriers to SME participation. For example, research has shown that SMEs find it difficult to identify contract opportunities in public sector markets, (e.g. Cabras, 2011; Loader, 2018). It is also widely acknowledged (e.g. Akenroye and Aju, 2013a; Flynn, 2016; Loader, 2011; Ringwald et al., 2009) that the financial requirements of public sector suppliers are too high for SMEs to meet. Associated with this are notions that public tender specifications are excessively prescriptive and, vague (Loader, 2015), with disproportionate evaluation criteria (Loader and Norton, 2015; Loader, 2011). These studies reported that the large size of public sector contracts discourages SMEs from taking part in the tendering process. The communication gap between public buyers and SMEs has also been identified as a major barrier to procurement participation (Kidalov, 2015).

(CAkenroye, T; Owens J D; Elbaz; J and Durowoju, O A.

British Process Management Journal: DOI 10.1108/BPMJ-10-2019-0447 


\subsubsection{Internal factors}

Several internal factors also constitute barriers. First, their small size means that SMEs are subject to internal resource and capacity constraints such as finance, human capital, IT skills, human resources, administrative skills and knowledge (Karjalainen and Kemppainen, 2008; Loader, 2013). This limits their chance of success in public tendering (Temponi and Cui, 2008) because resourceconstrained firms may not have the capacity to deliver public sector contracts, which are characteristically large or complex. Although governments (e.g. EU countries) have traditionally instructed public organisations to split large contracts into lots to attract small firms (Glas and Eßig, 2018), recent evidence found a large degree of non-compliance with the rule (Flynn and Davis, 2016). Given that contract bundling offers opportunities to get the best deals from a single supplier, this is perhaps unsurprising.

Furthermore, SMEs perceive the procurement process as costly and time-consuming (Loader, 2015; Flynn, 2016), so there is little time and financial commitment to submit a competitive bidding proposal. Although the widespread adoption of electronic systems in public organisations (Daou, Karuranga and Su, 2014; Centre for Economic and Business Research, 2013) is expected to streamline procurement processes and make bidding more efficient, evidence suggests that SMEs might lack computing systems or IT skills (Centre for Economic and Business Research and Gatewit, 2013). In addition, public procurement experts have expressed concerns about the inability of SMEs to align their service provisions with specific needs of the public sector (Michaelis, McGuire and Ferguson, 2003). For example, research has shown that SMEs often lack prior knowledge of tender participation, giving them little time to provide enough information when submitting tenders (e.g. Flynn, 2016; Loader, 2011, 2005).

While constraints in resources and capabilities are main barriers to SMEs in public sector markets, these are not insurmountable challenges. Many proponents of the RBV have argued that firms, particularly SMEs, can effectively respond to business challenges and competitive forces by paying attention to the pool of valuable, unique and rare resources they possess (e.g. Chandrakumara et al., 2011; Harreld, O'Reilly and Tushman, 2007; Hakala and Kohtamaki, 2011). This suggests they could draw on internal resources and capabilities to develop self-help strategies for tackling some of the internal challenges faced in public procurement, as shown in figure 1. Therefore, SMEs must possess appropriate resources that can be deployed to overcome barriers to the public procurement market, which falls within the firm's sphere of influence. However, resource and capability alone are insufficient to guarantee competitive advantage. Their configuration, integration and deployment are also significant. The next section examines how SMEs can take advantage of their resources and capabilities to address public procurement barriers.

\section{Theorising the links between DC and barriers to SME participation in public procurement}

The previous discussion has shown that there are several barriers hindering SMEs from effectively participating in public procurement. What emerges from an examination of the barriers is that there are opportunities for improvement based on the dynamic capability perspective. This section examines possible links between elements of dynamic capabilities (i.e. sensing, seizing, reconfiguring and learning) and the barriers facing SMEs in public sector markets. From the discussion, a set of propositions are put forward relating to the applicability of DC for improving SME participation in public procurement, summarised in Figure 3.

(CAkenroye, T; Owens J D; Elbaz; J and Durowoju, O A.

British Process Management Journal: DOI 10.1108/BPMJ-10-2019-0447 


\subsection{Sensing}

Figure 3 (file attached)

Sensing consists of "analytical systems to learn and to sense, filter, shape, and calibrate opportunities" (Teece, 2007). It enables organisations to acquire information that can help anticipate or better understand customer needs (Wagner et al., 2017). Lack of understanding of specification requirements has been cited by researchers (e.g. Akenroye and Aju, 2013a; Cabras, 2011) as a key barrier to SME participation in public procurement. Hence, small firms might need to develop "sensing" capabilities for collecting information to better understand the requirements of their public sector clients. One way to achieve this is to communicate more often with public buyers, to gain a clear understanding of what the needs are, and then put forward a strong bid/proposal.

To mobilise the resources needed to capture sensed opportunities effectively, SMEs should research their potential competitors, which offers insight into how they can win public contracts. By evaluating competitors' success, SMEs can identify weaknesses and opportunities for improvement, as well as develop resources that will be valuable in catching up with or outcompeting incumbent suppliers in the public sector markets. This gives rise to the following:

Proposition 1: The greater an SME's sensing capabilities, the more able the firm is to support its bid proposal with necessary information and to meet or exceed key requirements of the tender specification.

\subsection{Seizing}

Kindström et al. (2013) found that the development of dynamic capabilities depends on a firm's ability to make the most of sensed opportunities by innovatively addressing market needs. Other researchers (e.g. Saunila, 2014; Bayarçelik et al., 2014) have acknowledged the importance of seizing capabilities for designing business models to satisfy customers. The paper argues that innovation capability is key to the success of small firms, and critical for seizing opportunities that exist in a highly competitive market or crowded environment. This can be relevant in the context of the public procurement market, which is competitive by nature, and because public organisations are often confronted by multiple complex challenges (Daglio et al., 2014; Bayarçelik et al., 2014).

Identifying suppliers with innovative ideas to help solve these challenges is at the heart of public policy (OECD, 2017). Correspondingly, one of the unique competences attributed to small firms is innovation capability (Zawislak et al., 2012), and an ability to offer flexible and specialised services (Simionescu and Bica, 2014; Trzcieliński, 2016). Therefore, SMEs' innovation capabilities can be vital source of competitive advantage when participating in public sector markets. However, to propose innovative bids that align with the strategic needs of public organisations, SMEs must communicate frequently and consistently with procurement managers to understand the challenges they face in delivering public goods. It is therefore proposed that:

Proposition 2: The more an SME can pre-empt innovation challenges in the public sector, the better the firm's ability to develop products/services that appeal to the procurement decision makers.

Furthermore, to exploit new opportunities in the marketplace, a firm must build strategic networks or alliances (Teece, 2018; Alinaghian, Gregory and Srai, 2015) to add value through combined 
efforts. Similarly, two or more SMEs seeking to win public contracts can form a consortium to submit a bid. Through such collaborations, they can share/combine resources and capabilities to address certain barriers imposed by lack of experience or proven track record (Pickernell et al., 2011; Walker and Preuss, 2008), or lack of financial and or human resources (Karjalainen and Kemppainen, 2008; Loader, 2013). However, an SME's ability to build new alliances for seizing public contract opportunities will depend on the level of relational capital (Holienka et al., 2016) they possess. This has been referred to as a firm's willingness and ability to relate with clientele (Dyer and Singh, 1998). It can be a valuable resource when bidding for public procurement contracts, particularly with respect to consortium bidding. It is thus proposed that:

Proposition 3: The more an SME engages in network building, the more likely it is to mobilise additional resources to remedy internal resource restrictions, and the higher its ability to exploit consortium bidding to increase participation in public procurement.

\subsection{Reconfiguring}

There is consensus among researchers (e.g. Borch and Madsen, 2007; Teece, 2012; Helfat et al., 2007; Ambrosini and Bowman, 2009) that resource reconfiguration is the starting point for developing DC. There are two basic approaches that can be employed to reconfigure a firm's resource base to achieve competitive advantage in a dynamic environment (Dothan and Lavie, 2016): exploitative reconfiguration, or a firm's capacity to combine existing knowledge components, and exploratory reconfiguration, which combines new knowledge elements. Reconfiguration can play an important role in addressing the problem of contract size, which researchers (e.g. Cabras, 2011; Strömbäck, 2015) have identified as a key barrier to SME participation in public procurement.

Exploitative reconfiguration can help SMEs to identify areas where organisational resource-mix can be optimised to better satisfy tender specifications or contract requirements in the public sector. For example, where public authorities split contract opportunities into smaller lots (Glas and Eßig, 2018), SMEs may have to reconfigure scarce resources by allocating more time to the bids that most closely correspond with their speciality, rather than several lots. However, an SME may need first to assess its internal resources and capability against the public client's requirements, in order to identify the route that offers the best chance of success when bidding for contracts, e.g. determining whether to bid directly or jointly or to seek subcontracting opportunities. Hence, it is proposed that:

Proposition 4: SMEs possessing higher levels of exploitative reconfiguration capability are likely to allocate and coordinate internal firm resources to seize contract opportunities, matching their unique competencies.

\subsection{Learning}

Learning is a key catalyst of dynamic capabilities (He et al., 2018). It has been described as the essential investment that a firm makes towards acquiring the right knowledge for improving business performance (Sinkula et al., 1997). According to Gavin (1993), firms with a strong commitment to learning will develop a higher learning capability, which promotes the creation, acquisition and dissemination of knowledge, and in turn helps the firm to achieve competitive advantage (Slocum et al., 1994). Therefore, this paper argues that the more a firm continuously lays emphasis on the value of learning, the more likely it is to gain access to the necessary knowledge and skills to support its operations. This is relevant because lack of tendering skills has been

(CAkenroye, T; Owens J D; Elbaz; J and Durowoju, O A.

British Process Management Journal: DOI 10.1108/BPMJ-10-2019-0447 
identified as an important barrier to SME participation in public procurement (Loader, 2011, 2013). The role of organisational learning in SME performance and innovation is widely acknowledged in the literature (e.g. Michna, 2009; Rhee, Park and Lee, 2010; Wang et al., 2015). It is therefore logical to suggest that, if SMEs are open-minded and place a high value on learning, they may be able to learn new skills, which can help address knowledge gaps in bid writing. It is therefore proposed that:

Proposition 5: The more able an SME is to develop a commitment to learning, the better the firm's motivation to seek opportunities to address knowledge or skill deficits related to public sector tendering.

To develop commitment to learning, SMEs may require an open-minded view of the public procurement process. Open-mindedness is the process through which an organisation starts to erase prevailing knowledge or mindsets and accepts new realities readily (Beyene et al., 2016; Eshlaghy and Maatofi, 2011). Likewise, unsuccessful bidders may need to avoid ruminating on past experiences (negative), which can hinder them from accepting new ideas that are necessary to business transformation. It is therefore proposed that:

Proposition 6: The more open-minded an SME is, the greater its ability to develop resilience and coping strategies to handle unsuccessful public tendering outcomes.

Bessant, Kaplinsky and Morris (2003) argue that firms can develop capability through learning networks that provide access to peer-group support and others' experiences of responding to competitive challenges. In this way, firms can recognise dysfunctional practises and prevent strategic blind spots through collaboration (Teece, Pisano and Shuen, 1997). Social networking, particularly via online communities, also enables knowledge-sharing activities between firms which are essential to developing dynamic capabilities (e.g. Charband and Navimipour, 2016; Helfat and Peteraf, 2015). This presents a potential solution to another critical barrier facing SMEs: lack of knowledge about public bidding processes and lack of bid preparation skills.

Learning networks can enable SMEs to bring new strategic resources into the firm from external sources. This aids them in developing the skills needed to succeed when competing for public sector contracts. Examples of such network arrangements can be found in regional groups such as small business cooperative organisations, Chambers of Commerce, sector/industry associations and other umbrella organisations. These offer a viable opportunity for members to tap into a diversity of talent, capability and experience, thus acquiring necessary resource configuration. These arguments lead to the following proposition:

Proposition 7: The more inclined an SME is towards learning networks, the more able the firm is to access peer support for insight and practical strategies to address the challenges of public sector contract competition.

\section{Directions for Future Research}

A research model is proposed in Figure 2 showing the theoretical links between DC and SME participation in public procurement. It states that the four components of dynamic capabilities (i.e. sensing, seizing, reconfiguring and learning) are necessary to facilitate SMEs' bids for contracts in

(CAkenroye, T; Owens J D; Elbaz; J and Durowoju, O A.

British Process Management Journal: DOI 10.1108/BPMJ-10-2019-0447 
the public sector. The set of propositions put forward in this model can be converted into testable hypotheses to enhance future research into the importance of dynamic capabilities to firm performance in tendering for public contracts. However, as shown in the model, the proposed relationships affect SME ability to apply these capabilities in developing strategies for overcoming certain marketplace barriers. Below are some recommendations for future research in terms of theoretical, methodological and contextual issues.

\subsection{Future directions: Theory}

Many of the studies featured in the literature focus on policy measures and interventions designed by governments (e.g. Loader, 2017; Flynn and Davis, 2015, 2016). Only a few examine the relationship between internal capabilities, strategic orientations and the participation of SMEs in public procurement. For example, Reijonen et al. (2016) identify entrepreneurial orientation (i.e. innovation and proactiveness) as an important firm-specific competence for successful SME participation in public procurement. Tammi et al. (2014), however, found that SMEs resorting to market orientation are better positioned to participate actively in bidding for public sector procurement contracts.

So far, research linking a firm's resources and capabilities to the successful participation of SMEs in public procurements is scarce. Previous studies in this area (e.g. Flynn and Davis, 2016; Reijonen et al., 2016; Tammi et al., 2014) have drawn on relational capability and strategic orientation, but examined these separately rather than in terms of their combined effect. Future research might consider how different RBV and capability concepts interact with each other to affect collectively the performance of SMEs when competing for public sector contracts. There is also a rapidly growing body of literature evaluating the effectiveness of policy measures to support SMEs in public procurement (e.g. Kidalov and Snider, 2011; Reis and Cabral, 2015; Stake, 2014). However, scant critical attention has been paid to the organisational capabilities required to maximise the benefits of using these policy measures.

SMEs in EU countries, for instance, are expected to come together to submit joint bids for public contracts (Flynn and Davis, 2015). But evidence also suggests that consortium bidding is not an attractive route for small firms to conduct business with government (Loader and Norton, 2015). SMEs may lack motivation to engage in strategic collaboration for reasons such as lack of trust and complementary skills (Franco and Haase, 2015). This paper argues that the ability of SMEs to maximise the benefits associated with policy measures may depend on the proportion of relevant resources and capabilities at their disposal. Future research should therefore explore the reasons for the disinclination of SMEs to make use of policy measures that can help improve participation in public procurement.

Investigations into theory-building could illuminate the implications of Intellectual Capital for addressing barriers to SME participation in public procurement. Key components of Intellectual Capital are human capital, relational capital and structural capital (Harris, 2000; Jardon and Susana Martos, 2012). While evidence suggests that these capitals enable a firm to gain a competitive edge in the marketplace (Steenkamp and Kashyap, 2010), the implications regarding the barriers to SME participation in public procurement are yet to be addressed. For example, relational capital depicts the value inherent in relationships between clients, suppliers and other stakeholders (Holienka et al., 2016), which can also be a valuable resource when bidding for public procurement contracts.

(CAkenroye, T; Owens J D; Elbaz; J and Durowoju, O A.

British Process Management Journal: DOI 10.1108/BPMJ-10-2019-0447 


\subsection{Future directions: Methodology}

Quantitative methods have been widely used to test hypotheses about relationships between relational capability, procedural capability, tendering capability and SME participation in public procurement (e.g. Flynn and Davis, 2016c; Flynn, 2017). Other studies use multivariate analysis to examine the impact of entrepreneurial orientation and market orientation on SME activity in public sector tendering (e.g. Reijonen et al., 2016; Tammi et al., 2014, 2016). Some qualitative research methods, like case study and interviews, have been used (e.g. Loader, 2013, 2015, and 2017) to analyse the barriers facing SMEs in public procurement. However, a more robust qualitative technique, like phenomenography, might be more apt to investigating the ways in which SME managers consider their internal resources, capabilities and strategic orientations as vital sources of competitive advantage when bidding for public sector contracts. Longitudinal case studies should also be conducted to examine this phenomenon.

\subsection{Future directions: Contexts}

Existing studies linking capabilities and strategic orientations with SME activity in public procurement (e.g. Barney et al., 2001; Reijonen et al., 2016) mostly focus on developed countries. However, the political, economic, social and legal institutional structures in different countries might influence SME participation differently. Researchers might therefore compare the impacts of a firm's resources and capabilities on the rate of SME participation in public procurement across different countries or cultures. One should also note that the public sector consists of different institutions with different organisational cultures, objectives and modes of operation. These idiosyncratic features influence procurement practices and impact the reported experience of their SME suppliers.

As Loader and Norton (2015) recommend, "attempts to improve participation and success of SMEs in the public procurement process should give consideration to developing a distinct, sector-driven, remedy" because the public-sector is not homogeneous. Despite this, previous studies (e.g. Glover, 2008; Preuss and Walker, 2011) have tended to treat the public sector as a homogenous body. Future studies could, for example, test whether different types of public sector organisations (e.g. healthcare, education and housing) influence or moderate firms' ability to deploy resources and capabilities when competing for contracts.

\section{Conclusion}

This paper highlights what existing literature contributes to the nexus between SMEs and public procurement, with specific emphasis on barriers to participation, and it examines how dynamic capability concepts can address these barriers. Although prior research brings to fore different barriers facing SMEs in their efforts to supply the public sector, there are similarities in the approaches used to categorise the underlying causes of these barriers. To inform future debate, the barriers identified have been grouped into two broad categories of factors: external and internal. External factors have their roots in the structure and workings of public procurement activities. Internal factors relate to the characteristics of SMEs in general, such as resource and capability constraints, which may limit their participation in public tendering. The applicability of dynamic capabilities in addressing such barriers have been examined. Seven propositions have been derived to advance the theoretical understanding of the role of a firm's internal resources and capabilities in improving SME participation in public procurement.

(CAkenroye, T; Owens J D; Elbaz; J and Durowoju, O A.

British Process Management Journal: DOI 10.1108/BPMJ-10-2019-0447 
Previous studies (e.g. Loader, 2013; Tammi, Reijonen and Saastamoinen, 2014) have suggested the need for SMEs to develop self-help strategies to improve their chances of success in public procurement. This paper extends this argument from the dynamic capabilities perspective to examine how an SME firm's resources can be deployed and re-deployed. Such (re)deployments help develop strategic responses for tackling common barriers to participation in the public procurement marketplace. A model has been developed to portray the theorised relationships between different elements of the dynamic capabilities of a firm and the barriers identified. Thus, this paper contributes to the emerging body of literature emphasising the identification of strategies that can be adopted by SMEs to advance their participation in public procurement. This research can serve as useful guidance for SME owners or managers in how to maximise the value of their limited resources and capabilities in this regard.

Despite its contributions, this paper is based solely on a systematic literature review and theoretical analysis. Future studies could use meta-analysis to review multiple studies relating to the nexus between SMEs and public procurement, hence improving methodological rigour. This limitation can be explained, however. Meta-analysis combines the results of multiple scientific studies, but the number of studies included in this review is insufficient to perform statistical analysis of variables or conduct meta-regression or subgroup analyses.

\section{Reference}

Akenroye, T.O. and Aju, O., (2013a). A taxonomy of approaches for promoting SMEs access to public procurement market. Journal of Enterprising Culture, 21(03), pp.335-357.

Akenroye, T. O., \& Aju, O. (2013b). Barriers to SMEs participation in public procurement in Nigeria: some preliminary results. International Journal of Entrepreneurship and Innovation Management, 17, pp 314-328.

Alinaghian, L., \& Razmdoost, K. (2018). How do network resources affect firms' network-oriented dynamic capabilities?. Industrial Marketing Management, 71, pp. 79-94.

Alinaghian, L. S., Gregory, S. M., \& Srai, D. J. (2015). Operationalising dynamic capabilities: A Supply network configuration approach (Doctoral dissertation, University of Cambridge).

Ambrosini, V., Bowman, C., \& Collier, N. (2009). Dynamic capabilities: An exploration of how firms renew their resource base. British Journal of Management, 20, pp. S9-S24.

Ancarani, A., Di Mauro, C., Hartley, T., \& Tátrai, T. (2019). A Comparative Analysis of SME Friendly Public Procurement: Results from Canada, Hungary and Italy. International Journal of Public Administration, pp. 1-16.

Baker, W., Amir, G., \& Marcelo, P. G. (2009). The Role of Entrepeneural Orientation in Overcoming Known and Unknown Barriers to Foreign Entry. In Proceedings of the 2010 Academy of Marketing Science (AMS) Annual Conference: pp 97-97.

CAkenroye, T; Owens J D; Elbaz; J and Durowoju, O A.

British Process Management Journal: DOI 10.1108/BPMJ-10-2019-0447 
Barney, J. B. (2001). Resource-based theories of competitive advantage: A ten-year retrospective on the resource-based view. Journal of Management, 27(6), pp. 643-650.

Bayarçelik, E. B., Taşel, F., \& Apak, S. (2014). A research on determining innovation factors for SMEs. Procedia-Social and Behavioural Sciences, 150, pp. 202-211.

Bessant, J., Kaplinsky, R., \& Morris, M. (2003). Developing capability through learning networks. International Journal of Technology Management \& Sustainable Development, 2(1), pp. 19-38

Beyene, K. T., Shi, C. S., \& Wu, W. W. (2016). Linking culture, organizational learning orientation and product innovation performance: The case of Ethiopian manufacturing firms. South African Journal of Industrial Engineering, 27(1), pp. 88-101.

Booth, L. (2015). 'Public Procurement', Briefing Paper 6029, House of Commons Library, 3 July 2015, p.3. 59.

Borch, O. J., \& Madsen, E. L. (2007). Dynamic capabilities facilitating innovative strategies in SMEs. International Journal of Technoentrepreneurship, 1(1), pp. 109-125.

Burisch, R., \& Wohlgemuth, V. (2016). Blind spots of dynamic capabilities: A systems theoretic perspective. Journal of Innovation \& Knowledge, 1(2), pp. 109-116

Cabinet Office (2012). Procurement policy note 04/12: procurement supporting growth, supporting material for departments.

https://assets.publishing.service.gov.uk/government/uploads/system/uploads/attachment_data/file/ 62097/PPN-Procurement-Supporting-Growth.pdf (retrieved 21/10/2019)

Cabras, I. (2011). Mapping the spatial patterns of public procurement: a case study from a peripheral local authority in Northern England. International Journal of Public Sector Management, 24(3), pp.187-205.

Calantone, R. J., Cavusgil, S. T., \& Zhao, Y. (2002). Learning orientation, firm innovation capability, and firm performance. Industrial marketing management, 31(6), pp. 515-524.

Jardon, C. M., \& Susana Martos, M. (2012). Intellectual capital as competitive advantage in emerging clusters in Latin America. Journal of Intellectual Capital, 13(4), pp. 462-481.

Centre for Economic and Business Research. (2013). UK e-Procurement Trends. London: Gatewit

Chandrakumara, A., De Zoysa, A., \& Manawaduge, A. (2011). Effects of the entrepreneurial and managerial orientations of owner-managers on company performance: An empirical test in Sri Lanka. International Journal of Management, 28(1), pp. 139.

Charband, Y., \& Navimipour, N. J. (2016). Online knowledge sharing mechanisms: a systematic review of the state of the art literature and recommendations for future research. Information Systems Frontiers, 18(6), pp.1131-1151. 
Chauvet, V., \& Guiot-BP, C. (2002). Absorptive capacity and knowledge transfer propensity: towards the obtaining of a competitive advantage. Organizational Behavior and Human Decision Processes, 82(1), pp. 150-159.

Citroni, G., Lippi, A., \& Profeti, S. (2019). In the Shadow of Austerity: Italian Local Public Services and the Politics of Budget Cuts. In Local Public Services in Times of Austerity across Mediterranean Europe (pp. 115-140). Palgrave Macmillan, Cham.

Cohen, W. M., \& Levinthal, D. A. (1990). Absorptive capacity: A new perspective on learning and innovation. Administrative Science Quarterly, 35(1), pp. 128-152.

Common-Wealth (2010). Improving SMEs Access to the Public Procurement Market in Uganda. Draft report. (SASD/EAS/UGA/045). October 2010. [Online] Available: https://www.ppda.go.ug/download/UGA_SME_Procurement_Draft_8Oct10-1.pdf [Assessed August 22, 2019].

Creswell, J. W., \& Creswell, J. D. (2017). Research design: Qualitative, quantitative, and mixed methods approaches. Thousand Oaks, CA: Sage Publications.

Crossley, A., Coles, G., Edwards, R., Hurrell, S., \& Ruddle, N. (2015, October). The development and adoption of a new joint bidding system for public contracts in Wales. In Working Conference on Virtual Enterprises (pp. 622-630). Springer, Cham.

Daglio, M., Gerson, D., \& Kitchen, H. (2014, November). Building organisational capacity for public sector innovation. In Background Paper prepared for the OECD Conference Innovating the Public Sector: from Ideas to Impact, Paris (pp. 12-13).

Daou, A., Karuranga, E., \& Su, Z. (2014). Towards a better understanding of intellectual capital in Mexican SMEs. Journal of Intellectual Capital, 15(2), pp. 316-332.

Davis, P., \& Brady, O. (2015). Are government intentions for the inclusion of innovation and small and medium enterprises participation in public procurement being delivered or ignored? An Irish case study. Innovation: The European Journal of Social Science Research, 28(3), pp. 324-343.

Dawoody, A. (2012). Observing Public Policy in a Global Context. In Globalization-Approaches to Diversity. IntechOpen.

Dixon-Woods, M., Cavers, D., Agarwal, S., Annandale, E., Arthur, A., Harvey, J., ... \& Riley, R. (2006). Conducting a critical interpretive synthesis of the literature on access to healthcare by vulnerable groups. BMC Medical Research Methodology, 6(1), pp. 35.

Dothan, A., \& Lavie, D. (2016). Resource reconfiguration: Learning from performance feedback. In Resource redeployment and corporate strategy (pp. 319-369). Emerald Group Publishing Limited. 
Drnevich, P. L., \& Kriauciunas, A. P. (2011). Clarifying the conditions and limits of the contributions of ordinary and dynamic capabilities to relative firm performance. Strategic Management Journal, 32(3), pp. 254-279.

Easterby-Smith, M., Antonacopoulou, E., Graça, M., \& Ferdinand, J. (2006). Organizational learning and dynamic capabilities. Economic \& Social Research Council.

Eisenhardt, K. M., \& Martin, J. A. (2000). Dynamic capabilities: what are they? Strategic management journal, 21(10-11), pp.1105-1121.

Ensari, M. Ş., \& Karabay, M. E. (2014). What helps to make SMEs successful in global markets? Procedia-Social and Behavioural Sciences, 150, 192-201.

Eshlaghy, A. T., \& Maatofi, A. (2011). Learning orientation, innovation and performance: evidence from small-sized business firms in Iran. European Journal of Social Sciences, 19(1), pp.114-122.

Etuk, R. U., Etuk, G. R., \& Michael, B. (2014). Small and medium scale enterprises (SMEs) and Nigeria's economic development. Mediterranean Journal of Social Sciences, 5(7), pp. 656.

Federation of Small Businesses (2011), “Late payment”, available at: www.fsb.org.uk/LegacySitePath/policy/rpu/.../late\%20payment $\% 20$ july\%202011.pdf (accesse d 25 November 2019).

FreshMinds (2008). Evaluating SME Experiences of Government Procurement, Federation of Small Business. London, UK. http://shared.freshminds.co.uk/marketing/SME_Procurement_Report.pdf. Accessed 25 August 2019.

Fink, R. C., Hatten, K. J., Keeler, J. P., James, W. L., \& Edelman, L. F. (2017). Relational focus in long duration buyer-seller relationships. International Journal of Management and Decision Making, 16(1), pp. 73-96.

Flynn, A. (2016). Investigating compliance with SME-friendly procurement policy (Doctoral dissertation, Dublin City University).

Flynn, A. (2017). Re-thinking SME disadvantage in public procurement. Journal of Small Business and Enterprise Development, 24(4), pp. 991-1008.

Flynn, A., \& Davis, P. (2015). The rhetoric and reality of SME-friendly procurement. Public Money \& Management, 35(2), pp. 111-118.

Flynn, A., \& Davis, P. (2016). Firms' experience of SME-friendly policy and their participation and success in public procurement. Journal of Small Business and Enterprise Development, 23(3), pp.616-635.

Flynn, A., \& Davis, P. (2016b). The policy-practice divide and SME-friendly public procurement. Environment and Planning C: Government and Policy, 34(3), pp.559-578. 
Flynn, A., \& Davis, P. (2017). Investigating the effect of tendering capabilities on SME activity and performance in public contract competitions. International Small Business Journal, 35(4), pp. 449-469.

Franco, M., \& Haase, H. (2015). Interfirm alliances: a taxonomy for SMEs. Long Range Planning, 48(3), pp.168-181.

Gavin, D. (1993). “Building a learning organization.” Harvard Bus. Rev., 71(4), pp. 78-91

Georghiou, L., Edler, J., Uyarra, E., \& Yeow, J. (2014). Policy instruments for public procurement of innovation: Choice, design and assessment. Technological Forecasting and Social Change, 86, pp. 1-12.

Glas, A. H., \& Eßig, M. (2018). Factors that influence the success of small and medium-sized suppliers in public procurement: evidence from a centralized agency in Germany. Supply Chain Management: An International Journal, 23(1), pp. 65-78.

Glover, A. (2008). Accelerating the SME economic engine: through transparent, simple and strategic procurement. London: HM Treasury.

Graells, A. S. (2015). Public procurement and the EU competition rules. Bloomsbury Publishing.

Grandia, J., \& Meehan, J. (2017). Public procurement as a policy tool: using procurement to reach desired outcomes in society. International Journal of Public Sector Management, 30(4), pp. 302309.

Green Jr, K. W., Inman, R. A., Brown, G., \& Hillman Willis, T. (2005). Market orientation: relation to structure and performance. Journal of Business \& Industrial Marketing, 20(6), pp. 276-284.

Greenhalgh, T., Thorne, S., \& Malterud, K. (2018). Time to challenge the spurious hierarchy of systematic over narrative reviews?. European Journal of Clinical Investigation, 48(6).

Grimaldi, M., Quinto, I., \& Rippa, P. (2013). Enabling open innovation in small and medium enterprises: A dynamic capabilities approach. Knowledge and Process Management, 20(4), pp. 199-210.

Gruber, M., \& MacMillan, I. C. (2017). Entrepreneurial behavior: A reconceptualization and extension based on identity theory. Strategic Entrepreneurship Journal, 11(3), pp. 271-286.

Hakala, H. (2011). Strategic orientations in management literature: Three approaches to understanding the interaction between market, technology, entrepreneurial and learning orientations. International Journal of Management Reviews, 13(2), pp. 199-217.

Harris, L. (2000). A theory of intellectual capital. Advances in Developing Human Resources, 2(1), pp. 22-37. 
Hazlina Ahmad, N., Ramayah, T., Wilson, C., \& Kummerow, L. (2010). Is entrepreneurial competency and business success relationship contingent upon business environment? A study of Malaysian SMEs. International Journal of Entrepreneurial Behavior \& Research, 16(3), pp. 182203.

He, X., Huang, S. Z., Zhao, K., \& Wu, X. (2018). The Relationship between Learning Orientation and Dynamic Capability based on Environmental Education. EURASIA Journal of Mathematics, Science and Technology Education, 14(6), pp. 2193-2202.

Helfat, C. E. (1997). Know-how and asset complementarity and dynamic capability accumulation: the case of R\&D. Strategic management journal, 18(5), pp. 339-360.

Helfat, C. E., \& Peteraf, M. A. (2015). Managerial cognitive capabilities and the micro foundations of dynamic capabilities. Strategic Management Journal, 36(6), pp. 831-850.

Hillemane, B. S. M. (2012). Technological innovation in Indian SMEs: need, status and policy imperatives. Current opinion in creativity, innovation and entrepreneurship, 1(2).

Holienka, M., Pilková, A., \& Kubišová, M. (2016). The Influence of Intellectual Capital Performance on Value Creation in Slovak SMEs. In The Essence and Measurement of Organizational Efficiency (pp. 65-77). Springer, Cham.

Hotho, J. J., Lyles, M. A., \& Easterby-Smith, M. (2015). The mutual impact of global strategy and organizational learning: current themes and future directions. Global Strategy Journal, 5(2), pp. 85112.

Mokoena, B. A., \& Dhurup, M. (2016). Universities of Technology in Transition: In Search of the Inhibiting Factors to Market Orientation in a Developing Country. Journal of Social Sciences, 49(32), pp. 311-319.

Institute for Fiscal Studies (2015). Recent cuts to public spending. Retrieved from https://www.ifs.org.uk/tools_and_resources/fiscal_facts/public_spending_survey/cuts_to_public_s pending

Jardon, C. M., \& Susana Martos, M. (2012). Intellectual capital as competitive advantage in emerging clusters in Latin America. Journal of Intellectual Capital, 13(4), pp. 462-481.

Jerez Gómez, P., Céspedes Lorente, J. J., \& Valle Cabrera, R. (2004). Training practices and organisational learning capability: Relationship and implications. Journal of European industrial training, 28(2/3/4), 234-256.

Kaspar, L. and Puddephatt, A. (2012). Benefits of Transparency in Public Procurement for SMEs: General Lessons for Egypt, Cairo: Global Partners and Associates.

Karjalainen, K., \& Kemppainen, K. (2008). The involvement of small-and medium-sized enterprises in public procurement: Impact of resource perceptions, electronic systems and enterprise size. Journal of Purchasing and Supply Management, 14(4), pp. 230-240.

(CAkenroye, T; Owens J D; Elbaz; J and Durowoju, O A.

British Process Management Journal: DOI 10.1108/BPMJ-10-2019-0447 
Khalique, M., Shaari, N., Abdul, J., Isa, A. H. B. M., \& Ageel, A. (2011). Role of intellectual capital on the organizational performance of electrical and electronic SMEs in Pakistan. International Journal of Business and Management, 6(9).

Kidalov, M. V. (2015). Impact of contract bundling and consolidation on defense acquisition system and defense industrial base: The case of the us department of the navy. Journal of Public Procurement, 15(1), 1-37.

Kidalov, M. V., \& Snider, K. F. (2011). US and European public procurement policies for small and medium-sized enterprises (SME): a comparative perspective. Business and Politics, 13(4), pp.1-41.

Kindström, D., Kowalkowski, C., \& Sandberg, E. (2013). Enabling service innovation: A dynamic capabilities approach. Journal of business research, 66(8), pp.1063-1073.

Konno, Y. (2014) "An empirical analysis of the exit of SMEs tendering for public works in the Japanese construction industry", Journal of Financial Management of Property and Construction, 19 (2), pp.101- 116

Kreiser, P. M., Marino, L. D., Kuratko, D. F., \& Weaver, K. M. (2013). Disaggregating entrepreneurial orientation: the non-linear impact of innovativeness, proactiveness and risk-taking on SME performance. Small Business Economics, 40(2), pp. 273-291.

Kusumawardhani, A., McCarthy, G., \& Perera, N. (2009). Framework of entrepreneurial orientation and networking: a study of SMEs performance in a developing country. https://ro.uow.edu.au/gsbpapers/23/

Lamb, P., Sandberg, J., \& Liesch, P. W. (2011). Small firm internationalisation unveiled through phenomenography. Journal of International Business Studies, 42(5), pp.672-693.

Leontitsis, V., \& Ladi, S. (2018). The changing nature of European governance and the dynamics of Europeanization. In The Palgrave handbook of public administration and management in Europe (pp. 765-781). Palgrave Macmillan, London.

Liao, S. H., Chang, W. J., Wu, C. C., \& Katrichis, J. M. (2011). A survey of MO research (19952008). Industrial Marketing Management, (2), pp 301-310.

Lin, C., \& Tsai, H. L. (2016). Achieving a firm's competitive advantage through dynamic capability. Baltic Journal of Management, 11(3), pp. 260-285.

Loader, K. (2005). Supporting SMEs through government purchasing activity. The International Journal of Entrepreneurship and Innovation, 6(1), pp.17-26.

Loader, K. (2011). Are public sector procurement models and practices hindering small and medium suppliers? Public Money \& Management, 31(4), pp.287-294. 
Loader, K. (2013). Is public procurement a successful small business support policy? A review of the evidence. Environment and Planning C: Government and Policy, 31(1), pp. 39-55.

Loader, K. (2015). SME suppliers and the challenge of public procurement: Evidence revealed by a UK government online feedback facility. Journal of Purchasing and Supply Management, 21(2), pp.103-112.

Loader, K., \& Norton, S. (2015). SME access to public procurement: An analysis of the experiences of SMEs supplying the publicly funded UK heritage sector. Journal of Purchasing and Supply Management, 21(4), pp. 241-250.

Loader, K. (2018). Small-and medium-sized enterprises and public procurement: A review of the UK coalition government's policies and their impact. Environment and Planning C: Politics and Space, 36(1), pp 47-66.

Loon, M., Otaye-Ebede, L., \& Stewart, J. (2019). The paradox of employee psychological wellbeing practices: an integrative literature review and new directions for research. The International Journal of Human Resource Management, 30(1), 156-187.

MacLure, M. (2005),"'Clarity Bordering on Stupidity': Where's the Quality in Systemic Review," Journal of Educational Policy, 20 (No. 4, 2005), pp. 393-416.

Madrid-Guijarro, A., García-Pérez-de-Lema, D., \& Van Auken, H. E. (2014). How financing constraints is affecting SMEs' innovation during the economic crisis? In ICSB World Conference Proceedings (p. 1).

Maier, F., Meyer, M., \& Steinbereithner, M. (2016). Nonprofit organizations becoming businesslike: A systematic review. Nonprofit and Voluntary Sector Quarterly, 45(1), 64-86.

Maleki, A., Ansari, A., \& Safari, A. (2013). A Study of Market Orientation and Its Effect on Small to Medium Sized Enterprises of Informatics Industry Located in Tehran. Journal of Novel Applied Sciences, pp. 1150-1159.

Mason, R. B. (2007). The external environment's effect on management and strategy: a complexity theory approach. Management Decision, 45(1), pp. 10-28.

McGrath, H. (2008). Developing a relational capability construct for SME network marketing using cases and evidence from Irish and Finnish SMEs (Doctoral dissertation, Waterford Institute of Technology).

McKevitt, D., \& Davis, P. (2015). How to interact, when and with whom? SMEs and public procurement. Public Money \& Management, 35(1), pp. 79-86.

Medina-Arnáiz, R. (2010), Integrating gender equality in public procurement: the Spanish case. Journal of Public Procurement, 10, 4. pp. 540-563 
Michna, A. (2009). The relationship between organizational learning and SME performance in Poland. Journal of European industrial training, 33(4), pp356-370.

Mitran, D. (2013). Improving access of SMEs to the public procurement markets. Internal Auditing and Risk Management/Athenaeum University of Bucharest, 2, pp 244-251.

Mohsen, K., \& Eng, T. Y. (2016). The antecedents of cross-functional coordination and their implications for marketing adaptiveness. Journal of Business Research, 69(12), pp. 5946-5955.

O’Dwyer, M., \& Gilmore, A. (2019). Competitor orientation in successful SMEs: an exploration of the impact on innovation. Journal of Strategic Marketing, 27(1), pp 21-37.

OECD (2013). Government at a Glance 2013: Procurement Data. OECD Meeting of Leading Practitioners on Public Procurement. Available at:

http://www.oecd.org/gov/ethics/Government\%20at\%20a\%20Glance\%202013_Procurement\%20 Data\%20GOV_PGC_ETH_2013_2.pdf

OECD (2017). Fostering Innovation in the Public Sector, Paris: OECD Publishing.

Pedler, M., \& Burgoyne, J. G. (2017). Is the learning organisation still alive?. The Learning Organization, 24(2), pp. 119-126.

Patil, K. (2017). Public procurement policy for small and medium enterprises in developing countries: Evidence from India. International Journal of Public Sector Management, 30(4), 391410.

Peck, F., \& Cabras, I. (2011). The impact of local authority procurement on local economies: the case of Cumbria, North West England. Public Policy and Administration, pp. 26(3), 307-331.

Perry, C. (2011). Supporting SME access to public procurement opportunities. Research and Information Service Research Paper, 12(1), pp. 12-22.

Peteraf, M., Di Stefano, G., \& Verona, G. (2013). The elephant in the room of dynamic capabilities: Bringing two diverging conversations together. Strategic management journal, 34(12), pp. 1389-1410.

Pezeshkan, A., Fainshmidt, S., Nair, A., Frazier, M. L., \& Markowski, E. (2016). An empirical assessment of the dynamic capabilities-performance relationship. Journal of Business Research, 69(8), pp. 2950-2956.

Pickernell, D., Senyard, J., Jones, P., Packham, G., \& Ramsey, E. (2013). New and young firms: entrepreneurship policy and the role of government-evidence from the Federation of Small Businesses survey. Journal of Small Business and Enterprise Development, 20(2), pp. 358-382.

Pickernell, D., Kay, A., Packham, G., \& Miller, C. (2011). Competing agendas in public procurement: an empirical analysis of opportunities and limits in the UK for SMEs. Environment and Planning C: Government and Policy, 29(4), pp. 641-658. 
Pisano, G. P. (2017). Toward a prescriptive theory of dynamic capabilities: connecting strategic choice, learning, and competition. Industrial and Corporate Change, 26(5), pp. 747-762.

Podsakoff, P. M., Mackenzie, S. B., Bacharach, D. G., \& Podsakoff, N. P. (2005). The influence of management journals in the 1980s and 1990s. Strategic Management Journal, 26, 473-488

Preuss, L. (2011). On the contribution of public procurement to entrepreneurship and small business policy. Entrepreneurship \& Regional Development, 23(9-10), 787-814.

Preuss, L., \& Walker, H. (2011). Psychological barriers in the road to sustainable development: evidence from public sector procurement. Public Administration, 89(2), pp. 493-521.

Reijonen, H., \& Komppula, R. (2010). The adoption of market orientation in SMEs: required capabilities and relation to success. Journal of Strategic Marketing, 18(1), pp. 19-37.

Reijonen, H., Tammi, T., \& Saastamoinen, J. (2016). SMEs and public sector procurement: Does entrepreneurial orientation make a difference?. International Small Business Journal, 34(4), pp. 468-486.

Reis, P. R., \& Cabral, S. (2015). Public procurement strategy: the impacts of a preference programme for small and micro businesses. Public Money \& Management, 35(2), pp. 103-110.

Rhee, J., Park, T., \& Lee, D. H. (2010). Drivers of innovativeness and performance for innovative SMEs in South Korea: Mediation of learning orientation. Technovation, 30(1), pp. 65-75.

Ringwald, K., Lee, C., Williams, H., Cahill, D., \& Evans, C. (2009). Barriers to procurement opportunity research. Report prepared for welsh Assembly Government ${ }^{2}$ Value wales.

Saunila, M. (2014). Innovation capability for SME success: perspectives of financial and operational performance. Journal of Advances in Management Research, 11(2), pp. 163-175.

Schilke, O., Hu, S., \& Helfat, C. E. (2018). Quo vadis, dynamic capabilities? A content-analytic review of the current state of knowledge and recommendations for future research. Academy of Management Annals, 12(1), pp. 390-439.

Schreyögg, G., \& Kliesch-Eberl, M. (2007). How dynamic can organizational capabilities be? Towards a dual-process model of capability dynamization. Strategic Management Journal, 28(9), pp. 913-933.

Simionescu, S., \& Bica, E. (2014). Controversies And Comparisons Of Definition For Small And Medium-Sized Entreprises At Level Of European Union. Journal of Advanced Research in Management, 5 (2 (10) pp.74.

Sinkula, J. M., Baker, W. E., \& Noordewier, T. (1997). A framework for market-based organizational learning: Linking values, knowledge, and behavior. Academy of Marketing Science, 25(4), pp.305. 
Soininen, J., Martikainen, M., Puumalainen, K., \& Kyläheiko, K. (2012). Entrepreneurial orientation: Growth and profitability of Finnish small-and medium-sized enterprises. International Journal of Production Economics, 140(2), pp. 614-621.

Sprafke, N., Externbrink, K., \& Wilkens, U. (2012). Exploring micro-foundations of dynamic capabilities: insights from a case study in the engineering sector. In A focused issue on competence perspectives on new industry dynamics (pp. 117-152). Emerald Group Publishing Limited.

Srivastava, M., Franklin, A., \& Martinette, L. (2013). Building a sustainable competitive advantage. Journal of Technology Management \& Innovation, 8(2), pp.47-60.

Stake, J. (2014). SME participation and success in public procurement. In 6th International Public Procurement Conference.

Steenkamp, N., \& Kashyap, V. (2010). Importance and contribution of intangible assets: SME managers' perceptions. Journal of Intellectual Capital, 11(3), pp.368-390.

Stoian, M. C., Rialp, J., \& Dimitratos, P. (2017). SME networks and international performance: Unveiling the significance of foreign market entry mode. Journal of Small Business Management, 55(1), pp.128-148.

Strömbäck, E. (2015). Contract size and small firm competition in public procurement. Retrieved fromhttps://www.diva-portal.org/smash/get/diva2:849659/FULLTEXT01.pdf

Suliantoro, H., Winarno, B. A., \& Handayani, N. U. (2019). Analysing the Success Factors of SMEs on Public Procurement. In IOP Conference Series: Materials Science and Engineering (Vol. 598, No. 1, p. 012097

Tammi, T., Saastamoinen, J., \& Reijonen, H. (2014). Market orientation and smes' activity in public sector procurement participation. Journal of Public Procurement, 14(3), pp.304-327.

Tammi, T., Reijonen, H., \& Saastamoinen, J. (2017). Are entrepreneurial and market orientations of small and medium-sized enterprises associated with targeting different tiers of public procurement?. Environment and Planning C: Politics and Space, 35(3), pp. 457-475.

Teece, D. J. (2016). Dynamic capabilities and entrepreneurial management in large organizations: Toward a theory of the (entrepreneurial) firm. European Economic Review, 86, pp.202-216.

Teece, D. J. (2018). Business models and dynamic capabilities. Long Range Planning, 51(1), pp.4049.

Teece, D. J. (2014). A dynamic capabilities-based entrepreneurial theory of the multinational enterprise. Journal of International Business Studies, 45(1), pp 8-37.

Teece, D. J. (2015). Intangible assets and a theory of heterogeneous firms. In Intangibles, market failure and innovation performance (pp. 217-239). Springer, Cham. 
Teece, D. J. (2007). Explicating dynamic capabilities: the nature and microfoundations of (sustainable) enterprise performance. Strategic management journal, 28(13), pp.1319-1350.

Teece, D. J. (2012). Dynamic capabilities: Routines versus entrepreneurial action. Journal of management studies, 49(8), pp.1395-1401.

Teece David, J., Gary, P., \& Amy, S. (1997). Dynamic capabilities and strategic management. Strategic Management Journal, 18(7), pp.509-533.

Teece, D. J., Pisano, G., \& Shuen, A. (1997). Dynamic capabilities and strategic management. Strategic management journal, 18(7), pp. 509-533.

Temponi, C., \& Cui, W. (2008). Factors impacting participation of Hispanic small businesses in government contracting in the USA. Journal of Small Business and Enterprise Development, 15(3), pp. 504-526.

Trzcieliński, S. (2016). Flexibility of SMEs. In Advances in Ergonomics of Manufacturing: Managing the Enterprise of the Future (pp. 417-427). Springer, Cham.

Uyarra, E., Edler, J., Garcia-Estevez, J., Georghiou, L., \& Yeow, J. (2014). Barriers to innovation through public procurement: A supplier perspective. Technovation, 34(10), pp.631-645.

Wagner, D., Wenzel, M., Wagner, H. T., \& Koch, J. (2017). Sense, seize, and reconfigure; online communities as strategic assets. Journal of Business Strategy, 38(5), pp. 27-34.

Walker, H., \& Preuss, L. (2008). Fostering sustainability through sourcing from small businesses: public sector perspectives. Journal of Cleaner Production, 16(15), pp. 1600-1609.

Wang, K. Y., Hermens, A., Huang, K. P., \& Chelliah, J. (2015). Entrepreneurial orientation and organizational learning on SMEs' innovation. International Journal of Organizational Innovation.

Ward, M., \& Rhodes, C. (2014). Small Business and the UK Economy. Standard Note: SN/EP/6078.(9 December 2014). Economic Policy and Statistics. House of Commons Library.

Waring, T., \& Wainwright, D. (2008). Issues and challenges in the use of template analysis: Two comparative case studies from the field. Electronic Journal of Business Research Methods, 6(1).

Winter, S. G. (2003). Understanding dynamic capabilities. Strategic management journal, 24(10), pp. 991-995.

Yung-Chul, K. (2013). Learning Orientation, dynamic capabilities and performance in Korean high-tech ventures. Advances in Management.

Zahra, S., H. Sapienza and P. Davidsson (2006). 'Entrepreneurship and dynamic capabilities: a review, model and research agenda', Journal of Management Studies, 43, pp. 917-955. 
Zawislak, P. A., Cherubini Alves, A., Tello-Gamarra, J., Barbieux, D., \& Reichert, F. M. (2012). Innovation capability: From technology development to transaction capability. Journal of technology management \& innovation, 7(2), pp. 14-27.

Zhou, K. Z., Brown, J. R., \& Dev, C. S. (2009). Market orientation, competitive advantage, and performance: A demand-based perspective. Journal of business research, 62(11), pp.1063-1070.

Zott, C. (2003). Dynamic capabilities and the emergence of intraindustry differential firm performance: insights from a simulation study. Strategic Management Journal, 24(2), pp. 97-125. 
Figure 1. The systematic review procedure

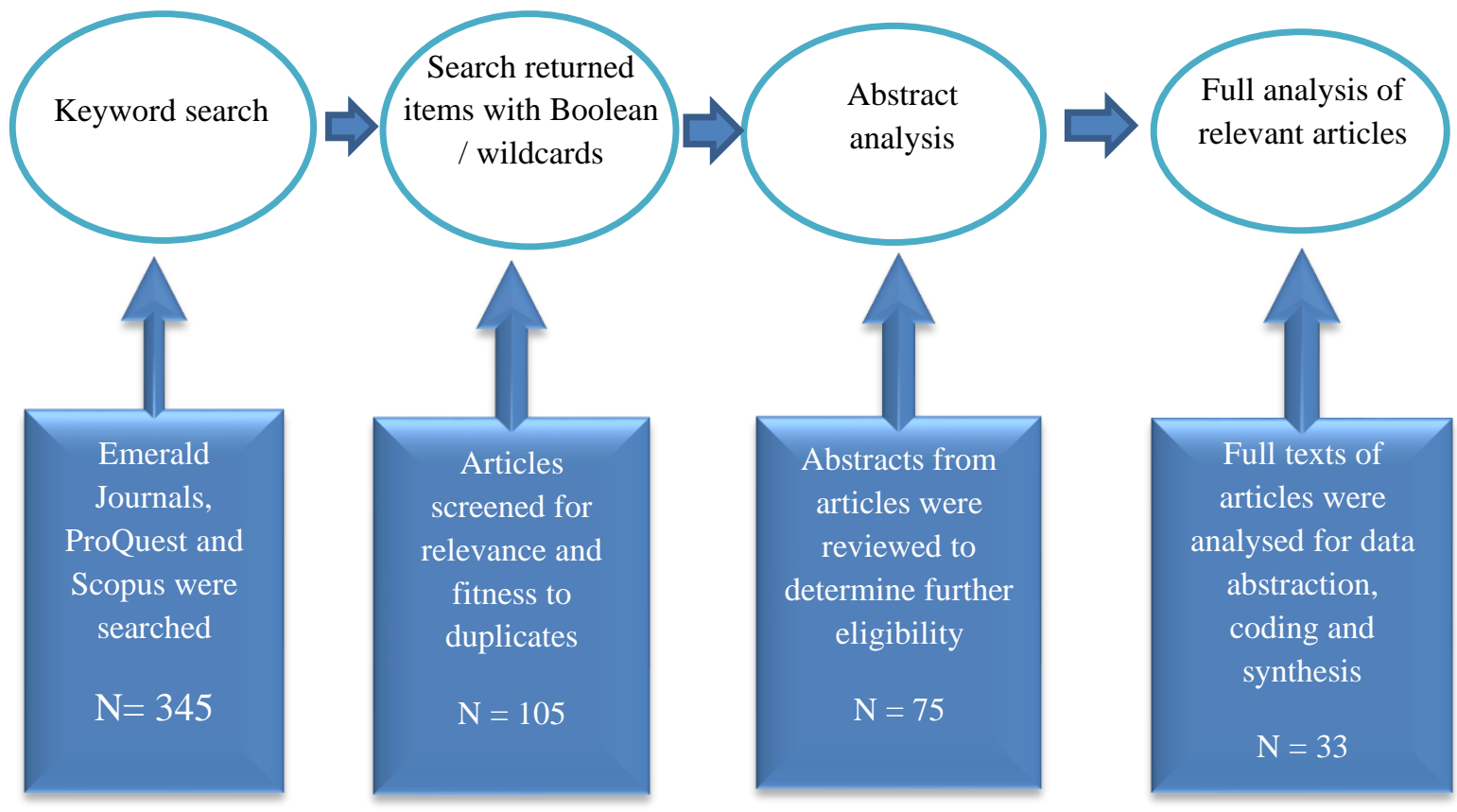

Figure 2. Classification of barriers to SME participation in public procurement

\section{EXTERNAL FACTORS}

\section{Barriers imposed by the public sector} environment

- Conflicting priorities (cost savings versus supplier diversity)

- Public buyers lack adequate skills to engage SMEs

- Pro-large supplier attitude

- Risk averse culture

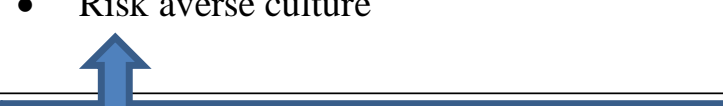

\section{BARRIERS ENCOUNTERED BY SMES IN PUBLIC SECTOR MARKETS}

\section{Barriers related to SMEs' capability}

- Lack adequate resources (legal, admin, marketing, human capital)

- Lack of knowledge about public bidding process

- Lack of bid preparation skills

- Lack of performance history or tract record

- Inability to align proposal to specific contract outcomes

- Lack of track record of performance

- Lack of systems or IT skills

- In ability to offer lower costs due to lack of economies of scale

\section{INTERNAL FACTORS}


Figure 3. Dynamic capabilities to improve SME participation in public procurement

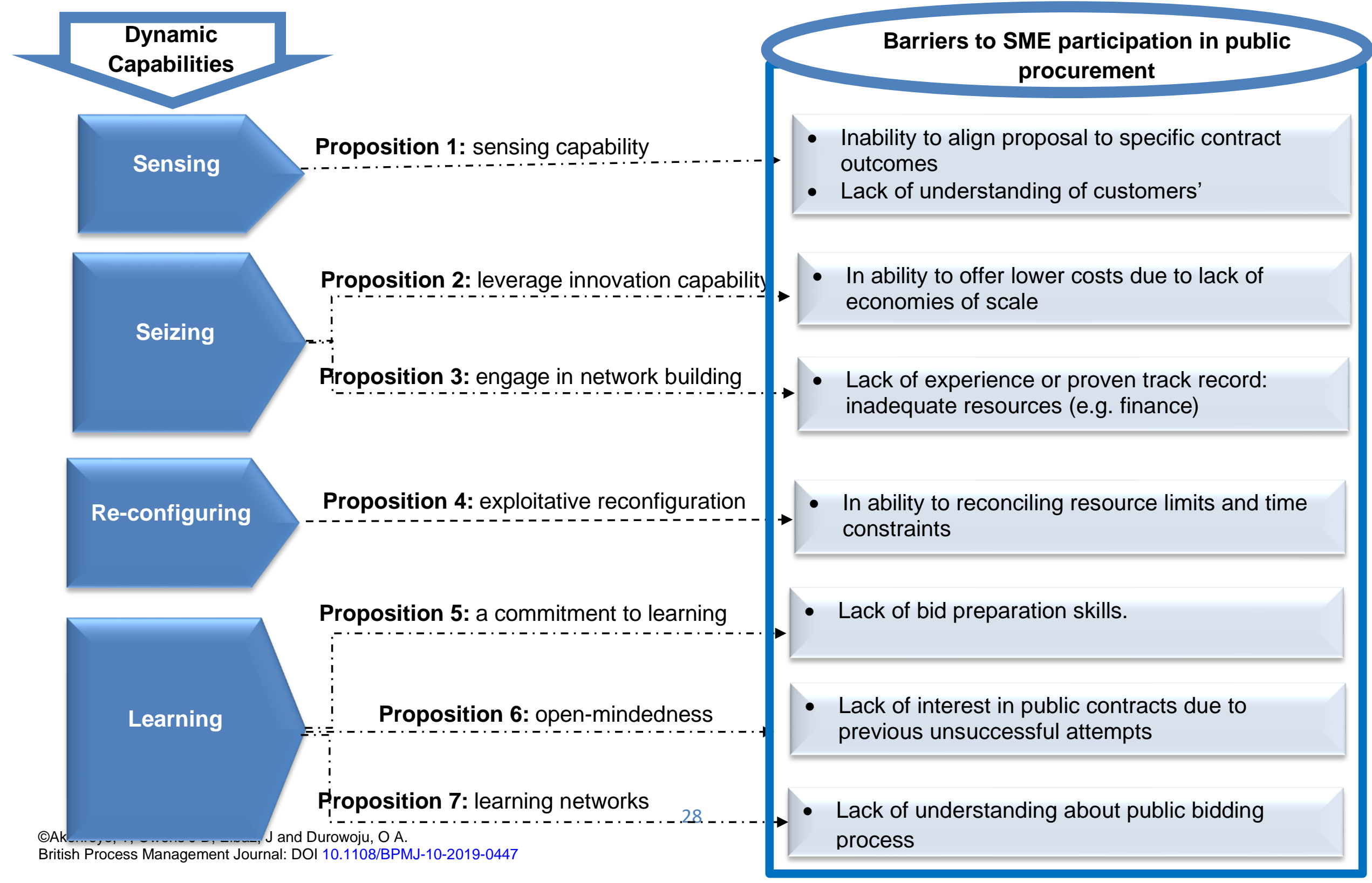


Table 1. Key element of a firm's dynamic capabilities

\begin{tabular}{|c|c|c|}
\hline Key Capabilities & Indicators & Authors \\
\hline Sensing & $\begin{array}{l}\text { The ability to: } \\
\text { Scan for and identify opportunities } \\
\text { Gather and evaluate market } \\
\text { information } \\
\text { Identify opportunities and assess } \\
\text { customer needs }\end{array}$ & $\begin{array}{l}\text { Teece (2007) } \\
\text { Sprafke, Externbrink and Wilkens } \\
\text { (2012) } \\
\text { Helfat (2009), } \\
\text { Wagner et al (2017), } \\
\text { Kindström et al (2013) } \\
\text { Alinaghian and Razmdoost (2018) }\end{array}$ \\
\hline Seizing & $\begin{array}{l}\text { The ability to: } \\
\text { - Develop innovative offerings } \\
\text { - Exploit sensed opportunities } \\
\text { - Develop new products/services } \\
\text { - Make better use of resources } \\
\quad \text { through networking }\end{array}$ & $\begin{array}{l}\text { Teece (2007) } \\
\text { Wagner et al (2017), } \\
\text { Pisano, (2017) } \\
\text { Alinaghian and Razmdoost (2018) } \\
\text { Gulati et al. (2011) }\end{array}$ \\
\hline Reconfiguring & $\begin{array}{l}\text { The ability to: } \\
\text { - Transforming internal } \\
\text { resources to matched sensed } \\
\text { opportunities } \\
\text { - Build new strategic assets } \\
\text { - Create and develop new } \\
\text { opportunities } \\
\text { - Form strategic alignment }\end{array}$ & $\begin{array}{l}\text { Helfat (2009), Teece (2012) } \\
\text { Burisch and Wohlgemuth (2016) } \\
\text { Borch and Madsen (2007) Teece } \\
\text { (2010) } \\
\text { Helfat et al., (2007) } \\
\text { Ambrosini and Bowman, (2009) } \\
\text { Alinaghian et al (2015) }\end{array}$ \\
\hline Learning & $\begin{array}{l}\text { The ability to: } \\
\text { - Demonstrate a strong } \\
\text { commitment to learning } \\
\text { - Acquire the right knowledge } \\
\text { - Become more open to new ideas } \\
\text { - Source external knowledge via } \\
\text { network building }\end{array}$ & $\begin{array}{l}\text { Easterby-Smith et al, (2006) } \\
\text { Beyene et al (2016) } \\
\text { Yung-Chul (2013) } \\
\text { Eshlaghy and Maatofi (2011) } \\
\text { Hotto et al (2015) } \\
\text { Pedler and Burgoyne (2017) } \\
\text { Alinaghian and Razmdoost (2018) }\end{array}$ \\
\hline
\end{tabular}

Table 2. Publications by country/region

\begin{tabular}{c|c} 
Country/region & Count \\
\hline USA & 2 \\
UK & 16 \\
Uganda & 1 \\
Romania & 1 \\
Nigeria & 2
\end{tabular}




\begin{tabular}{c|c} 
Multiple: USA and Europe & 1 \\
Japan & 1 \\
Ireland & 3 \\
India & 1 \\
Germany & 1 \\
Finland & 1 \\
Egypt & 1 \\
Brazil & 1
\end{tabular}

Table 3. Categories of publications included in the review

Categories of publications included in the review

Counts

\begin{tabular}{c|c}
\hline Operation research & 1 \\
Social science & 2 \\
Finance & 2 \\
Purchasing and supply & 5 \\
Politics and governance & 5 \\
Non-academic articles & 6 \\
Small business and entrepreneurship & 6 \\
Public administration and management & 6
\end{tabular}

Table 4. Articles classified based on methodology

\begin{tabular}{c|c} 
Methods & Counts \\
\hline Case study & 2 \\
Document analysis & 9 \\
Survey & 12 \\
Interview & 3 \\
Literature review & 2 \\
Mixed methods & 5
\end{tabular}


Appendix Table 1. The classification matrix for data abstraction

\begin{tabular}{|c|c|c|c|c|c|}
\hline Authors & Purpose/aim & Method & $\begin{array}{l}\text { Countr } \\
\mathbf{y}\end{array}$ & Findings/Outcomes & Journal \\
\hline $\begin{array}{l}\text { Akenroye, and } \\
\text { Aju (2013a). }\end{array}$ & $\begin{array}{l}\text { Explored the barriers hinder } \\
\text { SMEs from accessing public } \\
\text { sector contracts }\end{array}$ & $\begin{array}{l}\text { Mixed methods: } \\
\text { document } \\
\text { analysis and } \\
\text { semi-structured } \\
\text { interviews }\end{array}$ & Nigeria & $\begin{array}{l}\text { Lack of transparency in tendering } \\
\text { process was identified as the major } \\
\text { barrier }\end{array}$ & $\begin{array}{l}\text { Journal of Enterprising } \\
\text { Culture }\end{array}$ \\
\hline $\begin{array}{l}\text { Akenroyeand } \\
\text { Aju (2013b). }\end{array}$ & $\begin{array}{l}\text { An empirical study to understand } \\
\text { the factor structure of barriers } \\
\text { facing SMEs in public } \\
\text { procurement and their impacts }\end{array}$ & Survey & Nigeria & $\begin{array}{l}\text { Four barrier factors were extracted } \\
\text { using factor analysis namely; } \\
\text { information obscurity, incapability, } \\
\text { ignorance of procedures and arduous } \\
\text { and stringent process }\end{array}$ & $\begin{array}{l}\text { Journal of Entrepreneurship } \\
\text { and Innovation Management }\end{array}$ \\
\hline Cabras (2011) & $\begin{array}{l}\text { Investing the impact of public } \\
\text { procurement activity in a local } \\
\text { authority in Northern England on } \\
\text { local supply chain }\end{array}$ & $\begin{array}{l}\text { Mixed methods; } \\
\text { interview and } \\
\text { questionnaires }\end{array}$ & UK & $\begin{array}{l}\text { Barriers include, contract award } \\
\text { based on lowest prices instead of } \\
\text { value for money; complex } \\
\text { procurement process; Long and costly } \\
\text { bidding processes }\end{array}$ & $\begin{array}{l}\text { International Journal of } \\
\text { Public Sector Management }\end{array}$ \\
\hline $\begin{array}{l}\text { Flynn and } \\
\text { Davis (2016). }\end{array}$ & $\begin{array}{l}\text { An evaluation of impact of SME- } \\
\text { friendly policy on participation } \\
\text { and success rates in tendering }\end{array}$ & $\begin{array}{l}\text { Survey data from } \\
2755 \text { SME } \\
\text { respondents }\end{array}$ & Ireland & $\begin{array}{l}\text { SME-friendly policy has a significant } \\
\text { effect on success rates of SMEs in } \\
\text { public tendering but does not impact } \\
\text { on the frequency of participation }\end{array}$ & $\begin{array}{l}\text { Journal of Small Business } \\
\text { and Enterprise Development }\end{array}$ \\
\hline $\begin{array}{l}\text { Georghiou et } \\
\text { al (2014) }\end{array}$ & $\begin{array}{l}\text { Evaluates how public } \\
\text { procurement policy influences a } \\
\text { firm's innovation capabilities and } \\
\text { performance }\end{array}$ & $\begin{array}{l}\text { Survey; of } 800 \\
\text { public sector } \\
\text { suppliers }\end{array}$ & UK & $\begin{array}{l}\text { Too much emphasis on price and lack } \\
\text { of interaction with public bodies are } \\
\text { identified as the most significant } \\
\text { barriers }\end{array}$ & $\begin{array}{l}\text { Technological Forecasting } \\
\text { and Social Change, }\end{array}$ \\
\hline $\begin{array}{l}\text { Karjalainen } \\
\text { and } \\
\text { Kemppainen } \\
(2008) \text {. }\end{array}$ & $\begin{array}{l}\text { Examined the impact of SMEs' } \\
\text { perception of resources on } \\
\text { participation in public } \\
\text { procurement }\end{array}$ & $\begin{array}{l}\text { Survey; of } 5091 \\
\text { Finish SMEs }\end{array}$ & Finland & $\begin{array}{l}\text { Low SME participation is predicted } \\
\text { by perceived lack of resources i.e. } \\
\text { legal expertise and administration }\end{array}$ & $\begin{array}{l}\text { Journal of Purchasing and } \\
\text { Supply Management }\end{array}$ \\
\hline
\end{tabular}




\begin{tabular}{|c|c|c|c|c|c|}
\hline Kidalov (2015) & $\begin{array}{l}\text { Examined whether the bundling } \\
\text { and merging of public contracts } \\
\text { present challenges for small } \\
\text { suppliers }\end{array}$ & $\begin{array}{l}\text { Document } \\
\text { analysis }\end{array}$ & USA & $\begin{array}{l}\text { Consolidation and bundling of } \\
\text { contracts were weighing down overall } \\
\text { small business performance. }\end{array}$ & $\begin{array}{l}\text { Journal of Public } \\
\text { Procurement }\end{array}$ \\
\hline $\begin{array}{l}\text { Loader and } \\
\text { Norton }(2015)\end{array}$ & $\begin{array}{l}\text { A sector focused evaluation of the } \\
\text { experiences of small suppliers in } \\
\text { the UK Heritage public } \\
\text { procurement environment }\end{array}$ & Interview & UK & $\begin{array}{l}\text { Issues discouraging SMEs from } \\
\text { participation include reluctance to } \\
\text { form consortia, disinclination for } \\
\text { subcontracting and lack of } \\
\text { demonstrating a track record }\end{array}$ & $\begin{array}{l}\text { Journal of Purchasing and } \\
\text { Supply Management }\end{array}$ \\
\hline $\begin{array}{l}\text { Loader } \\
\text { (2011). }\end{array}$ & $\begin{array}{l}\text { Examined the extent to which the } \\
\text { procurement practices of public } \\
\text { bodies influence SME } \\
\text { participation in contracting } \\
\text { process }\end{array}$ & $\begin{array}{l}\text { Survey; of } 388 \\
\text { public authorities }\end{array}$ & UK & $\begin{array}{l}\text { SMEs are more likely to perform } \\
\text { better when contract award decisions } \\
\text { are based on value-for-money. An } \\
\text { increasing emphasis on cost tends to } \\
\text { discourage SME participation }\end{array}$ & $\begin{array}{l}\text { Public Money \& } \\
\text { Management }\end{array}$ \\
\hline Loader (2013) & $\begin{array}{l}\text { A critical review of the literature } \\
\text { identifying policies to encourage } \\
\text { SME suppliers in the UK's public } \\
\text { sector markets. }\end{array}$ & Literture review & UK & $\begin{array}{l}\text { - Some of the barriers identified twenty } \\
\text { years ago, still remain. Two broad } \\
\text { categories of sources of barriers } \\
\text { emerged i.e. public sector and Small } \\
\text { business sector Capacity }\end{array}$ & $\begin{array}{l}\text { Environment and Planning C: } \\
\text { Government and Policy }\end{array}$ \\
\hline Loader (2015) & $\begin{array}{l}\text { Barriers previously identified in } \\
\text { the literature were not discovered } \\
\text { from the study, such as contract } \\
\text { size, contract length and supplier } \\
\text { rationalization }\end{array}$ & Survey: online & UK & $\begin{array}{l}\text { - SMEs perceive the public } \\
\text { procurement process as frustrating } \\
\text { and biased. The need to act as } \\
\text { subcontractors was identified as a } \\
\text { concern }\end{array}$ & $\begin{array}{l}\text { Journal of Purchasing and } \\
\text { Supply Management }\end{array}$ \\
\hline Loader (2017). & $\begin{array}{l}\text { A critical review of SME-friendly } \\
\text { procurement policy adopted by } \\
\text { the UK coalition government } \\
\text { between 2010- } 2015\end{array}$ & $\begin{array}{l}\text { Document } \\
\text { analysis }\end{array}$ & UK & $\begin{array}{l}\text { SMEs are less aware of the policy } \\
\text { measure available for their benefits }\end{array}$ & $\begin{array}{l}\text { Environment and Planning C: } \\
\text { Politics and Space }\end{array}$ \\
\hline $\begin{array}{l}\text { Pickernell et al } \\
\text { (2013). }\end{array}$ & $\begin{array}{l}\text { Key differences between new, } \\
\text { young and older firms in terms of } \\
\text { firm characteristics and } \\
\text { performance }\end{array}$ & $\begin{array}{l}\text { Survey; involving } \\
8,000 \text { respondents } \\
\text { from UK }\end{array}$ & UK & $\begin{array}{l}\text { - New and young firms SMEs are } \\
\text { relying on external networks to } \\
\text { address their resource limitations }\end{array}$ & $\begin{array}{l}\text { Journal of Small Business } \\
\text { and Enterprise Development }\end{array}$ \\
\hline
\end{tabular}




\begin{tabular}{|c|c|c|c|c|c|}
\hline & & $\begin{array}{l}\text { Federation of } \\
\text { Small Businesses }\end{array}$ & & & \\
\hline $\begin{array}{l}\text { Ringwald et al } \\
\text { (2009) }\end{array}$ & $\begin{array}{l}\text { A review supplier pre- } \\
\text { qualification practices across } \\
\text { public sector organisations in } \\
\text { Wales to determine barriers to } \\
\text { engagement with SMEs }\end{array}$ & Survey & UK & $\begin{array}{l}\text { SMEs experience a lot of issues } \\
\text { ranging from the complexity of the } \\
\text { public sector procurement process; a } \\
\text { lack of transparency in the evaluation } \\
\text { and feedback process and the use of } \\
\text { non-contract specific risk criteria }\end{array}$ & Non-academic article \\
\hline $\begin{array}{l}\text { Peck and } \\
\text { Cabras (2011) }\end{array}$ & $\begin{array}{l}\text { Examines the impact of } \\
\text { procurement practices of local } \\
\text { authorities on local economies }\end{array}$ & $\begin{array}{l}\text { Document } \\
\text { analysis; } \\
\text { procurement } \\
\text { spends }\end{array}$ & UK & - Resource requirements are prohibitive & $\begin{array}{l}\text { Public Policy and } \\
\text { Administration }\end{array}$ \\
\hline $\begin{array}{l}\text { Pickernell et al } \\
\text { (2011) }\end{array}$ & $\begin{array}{l}\text { How the competing agendas in } \\
\text { public procurement sectors limit } \\
\text { SMEs participation }\end{array}$ & $\begin{array}{l}\text { Survey; involving } \\
8,000 \text { respondents } \\
\text { from UK } \\
\text { Federation of } \\
\text { Small Businesses }\end{array}$ & UK & $\begin{array}{l}\text { - SMEs lack appropriate resources and } \\
\text { skills to tender effectively }\end{array}$ & $\begin{array}{l}\text { Environment and Planning C: } \\
\text { Politics and Space }\end{array}$ \\
\hline Preuss (2011) & $\begin{array}{l}\text { Examined procurement mangers' } \\
\text { perception on the drivers and } \\
\text { enablers of procurement from } \\
\text { small business sector }\end{array}$ & $\begin{array}{l}\text { Case study } \\
\text { approach }\end{array}$ & UK & $\begin{array}{l}\text { Devolved processes produce } \\
\text { complexity, confusion, and } \\
\text { inconsistency }\end{array}$ & $\begin{array}{l}\text { Entrepreneurship and } \\
\text { Regional Development }\end{array}$ \\
\hline $\begin{array}{l}\text { Walker and } \\
\text { Preuss (2008) }\end{array}$ & $\begin{array}{l}\text { An analysis of opportunities for } \\
\text { driving sustainable developing } \\
\text { through sourcing from SMEs }\end{array}$ & $\begin{array}{l}\text { Case study } \\
\text { approach }\end{array}$ & UK & $\begin{array}{l}\text { - Risk-averse attitudes of public sector } \\
\text { buyers }\end{array}$ & Journal of Cleaner Production \\
\hline $\begin{array}{l}\text { FreshMinds } \\
(2008)\end{array}$ & $\begin{array}{l}\text { A study conducted to understand } \\
\text { ways to increase SMEs } \\
\text { participation in public } \\
\text { procurement }\end{array}$ & $\begin{array}{l}\text { Mixed methods- } \\
\text { survey \& } \\
\text { interviews }\end{array}$ & UK & $\begin{array}{l}\text { Approximately } 75 \% \text { of SMEs hardly } \\
\text { or at no time bid for government } \\
\text { work. } \\
\text { - More than } 75 \% \text { of SMEs believe } \\
\text { that there is limited awareness on } \\
\text { available government contract } \\
\text { opportunities } \\
\text { - Over } 50 \% \text { of SMEs feel that the }\end{array}$ & Non-academic article \\
\hline
\end{tabular}




\begin{tabular}{|c|c|c|c|c|c|}
\hline & & & & $\begin{array}{l}\text { tendering process for government } \\
\text { contracts is time consuming } \\
\text { - There were concerns about the } \\
\text { paper works/formality and unrealistic } \\
\text { timescales requirement from public } \\
\text { sector clients } \\
\text { Risk-averse attitudes of public sector } \\
\text { buyers }\end{array}$ & \\
\hline Glover (2008) & $\begin{array}{l}\text { Exploring how the government } \\
\text { can benefit from the innovation } \\
\text { and better value for money that } \\
\text { small suppliers can offer to the } \\
\text { public organisations }\end{array}$ & $\begin{array}{l}\text { Mixed - survey \& } \\
\text { interviews }\end{array}$ & UK & $\begin{array}{l}\text { It was also discovered that SMEs } \\
\text { don't get detailed feedback about } \\
\text { their performance in previous tender } \\
\text { contest. The competing policy } \\
\text { priorities in the public sector was } \\
\text { identified as another major barrier. }\end{array}$ & Non-academic article \\
\hline $\begin{array}{l}\text { Temponi and } \\
\text { Cui (2008). }\end{array}$ & $\begin{array}{l}\text { The impact of financial status and } \\
\text { e-commerce components on } \\
\text { Hispanic small businesses' ability } \\
\text { to gain access to government } \\
\text { procurement. }\end{array}$ & $\begin{array}{l}\text { Survey; data from } \\
\text { a random sample } \\
\text { of } 206 \text { firms }\end{array}$ & USA & $\begin{array}{l}\text { Firm's financial status has no impact } \\
\text { on ability to pursuing contracts, but } \\
\text { influence rate of contracts secured. }\end{array}$ & $\begin{array}{l}\text { Journal of Small Business } \\
\text { and Enterprise Development }\end{array}$ \\
\hline $\begin{array}{l}\text { Ward and } \\
\text { Rhodes (2014) }\end{array}$ & $\begin{array}{l}\text { An assessment of the role small } \\
\text { businesses in the UK economy to } \\
\text { provide evidence regarding } \\
\text { policies to make it easier for } \\
\text { SMEs to access public sector } \\
\text { procurement }\end{array}$ & $\begin{array}{l}\text { Document } \\
\text { analysis: data } \\
\text { from } 380 \text { contract } \\
\text { award files }\end{array}$ & UK & $\begin{array}{l}\text { - Evidence of late payment of small } \\
\text { firms supplying the public }\end{array}$ & Non-academic article \\
\hline $\begin{array}{l}\text { Glas and Eßig } \\
\text { (2018). }\end{array}$ & $\begin{array}{l}\text { It tests the assumption is that } \\
\text { SMEs have better chances of } \\
\text { winning public contracts when } \\
\text { tenders are split into lots }\end{array}$ & $\begin{array}{l}\text { Document } \\
\text { analysis }\end{array}$ & $\begin{array}{l}\text { German } \\
\mathrm{y}\end{array}$ & $\begin{array}{l}\text { A higher number of lots in a tender } \\
\text { does not significantly increase the } \\
\text { success rate of SMEs }\end{array}$ & $\begin{array}{l}\text { Supply Chain Management: } \\
\text { An International Journal }\end{array}$ \\
\hline $\begin{array}{l}\text { Kidalov and } \\
\text { Snider (2011) }\end{array}$ & $\begin{array}{l}\text { Offers a comparative view of the } \\
\text { use of public procurement as a }\end{array}$ & $\begin{array}{l}\text { Document } \\
\text { analysis: } \\
\text { secondary data }\end{array}$ & $\begin{array}{l}\text { Multipl } \\
\text { e:USA }\end{array}$ & $\begin{array}{l}\text { - SMEs face comparable barriers in } \\
\text { Europe and USA. Few existing } \\
\text { studies offer understanding regarding }\end{array}$ & Business and Politics \\
\hline
\end{tabular}




\begin{tabular}{|c|c|c|c|c|c|}
\hline & $\begin{array}{l}\text { tool to develop SMEs in USA and } \\
\text { Europe. }\end{array}$ & & $\begin{array}{l}\text { and } \\
\text { Europe }\end{array}$ & $\begin{array}{l}\text { the effectiveness of various policy } \\
\text { approaches to increasing SMEs } \\
\text { participation in public procurement }\end{array}$ & \\
\hline $\begin{array}{l}\text { Davis and } \\
\text { Brady (2015) }\end{array}$ & $\begin{array}{l}\text { An appraisal of the } \\
\text { implementation of European } \\
\text { Union (EU) policies on inclusion } \\
\text { of SMEs and innovation in public } \\
\text { procurement processes in Irish } \\
\text { institutions }\end{array}$ & Interviews & Ireland & $\begin{array}{l}\text { Lack of commitment from top } \\
\text { management, conflicting political } \\
\text { agenda and lower risk taking } \\
\text { prosperity }\end{array}$ & $\begin{array}{l}\text { European Journal of Social } \\
\text { Science Research }\end{array}$ \\
\hline $\begin{array}{l}\text { Kaspar and } \\
\text { Puddephatt } \\
\text { (2012) }\end{array}$ & $\begin{array}{l}\text { Appraise the challenges facing } \\
\text { SMEs when participating in } \\
\text { public procurement process from } \\
\text { a developing country's } \\
\text { perspective. }\end{array}$ & $\begin{array}{l}\text { Document } \\
\text { analysis }\end{array}$ & Egypt & $\begin{array}{l}\text { - SMEs barriers include: } \\
\text { - Lack of clear regulatory framework } \\
\text { and guidelines open to public scrutiny } \\
\text { and supported by adequate } \\
\text { enforcement mechanisms } \\
\text { - Poor accessibility } \\
\text { - Inadequate advertising of } \\
\text { opportunities }\end{array}$ & Non-academic article \\
\hline Konno (2014) & $\begin{array}{l}\text { Explored the factors that affect the } \\
\text { pulling out of SMEs from public } \\
\text { procurement in Japan. }\end{array}$ & $\begin{array}{l}\text { Document } \\
\text { analysis: } \\
\text { secondary data }\end{array}$ & Japan & $\begin{array}{l}\text { - Financial performance indicators such } \\
\text { as cash flow from operations and } \\
\text { capital and non-financial performance } \\
\text { like years of experience significantly } \\
\text { affect SME exits }\end{array}$ & $\begin{array}{l}\text { Journal of Financial } \\
\text { Management of Property and } \\
\text { Construction }\end{array}$ \\
\hline $\begin{array}{l}\text { Reis, P. R., \& } \\
\text { Cabral, S. } \\
(2015)\end{array}$ & $\begin{array}{l}\text { An evaluation of the impact of } \\
\text { procurement policy interventions } \\
\text { on designed to encourage small } \\
\text { and micro businesses }\end{array}$ & $\begin{array}{l}\text { Document } \\
\text { analysis }\end{array}$ & Brazil & $\begin{array}{l}\text { - SMEs were more likely to have their } \\
\text { contracts terminated as a result of } \\
\text { poor performance. }\end{array}$ & $\begin{array}{l}\text { Public Money \& } \\
\text { Management, }\end{array}$ \\
\hline $\begin{array}{l}\text { Commonwealt } \\
\text { h (2010) }\end{array}$ & $\begin{array}{l}\text { A review of factors influencing } \\
\text { SMEs in public procurement in } \\
\text { Uganda }\end{array}$ & $\begin{array}{l}\text { Mixed - survey \& } \\
\text { interviews }\end{array}$ & Uganda & $\begin{array}{l}\text { - Insufficient knowledge", "Lack of } \\
\text { feedback" and a "lack of } \\
\text { opportunities to meet buyers" } \\
\text { are the most frequently cited barriers }\end{array}$ & Non-academic article \\
\hline
\end{tabular}




\begin{tabular}{|c|c|c|c|c|c|}
\hline Mitran (2013). & $\begin{array}{l}\text { This paper provides overviews of } \\
\text { the main barriers to entry for } \\
\text { SMEs into the public procurement } \\
\text { markets, as well as a series of } \\
\text { measures designed to support } \\
\text { their access to a greater } \\
\text { proportion. }\end{array}$ & Survey & $\begin{array}{l}\text { Romani } \\
\text { a }\end{array}$ & $\begin{array}{l}\text { - The lack of stability of the } \\
\text { Romanian public procurement } \\
\text { legislation } \\
\text { - The lack of knowledge and skills for } \\
\text { bidding }\end{array}$ & $\begin{array}{l}\text { Internal Auditing and Risk } \\
\text { Management/Athenaeum } \\
\text { University of Bucharest, }\end{array}$ \\
\hline $\begin{array}{l}\text { Grandia and } \\
\text { Meehan } \\
\text { (2017). }\end{array}$ & $\begin{array}{l}\text { An assessment of the social } \\
\text { impact of procurement policy }\end{array}$ & Literature review & N/A & $\begin{array}{l}\text { - Authorities' selection criteria tend to } \\
\text { be relatively fixed, and wider policy } \\
\text { goals increase outcome uncertainty }\end{array}$ & $\begin{array}{l}\text { International Journal of } \\
\text { Public Sector Management, }\end{array}$ \\
\hline Patil (2017). & $\begin{array}{l}\text { Exploring SME procurement } \\
\text { policy from a developing country } \\
\text { context. }\end{array}$ & $\begin{array}{l}\text { Interviews: with } \\
20 \text { public sector } \\
\text { enterprises }\end{array}$ & India & $\begin{array}{l}\text { Barriers related "lack of policy- } \\
\text { administrative capacity compounded } \\
\text { by the prevalence of "efficiency } \\
\text { syndrome" on the part of procurers" }\end{array}$ & $\begin{array}{l}\text { International Journal of } \\
\text { Public Sector Management, }\end{array}$ \\
\hline Flynn (2017) & $\begin{array}{l}\text { The purpose was to examine the } \\
\text { association between firm size, } \\
\text { resources, capabilities and SME } \\
\text { participation in public } \\
\text { procurement. }\end{array}$ & $\begin{array}{l}\text { Survey: analysed } \\
\text { using regression } \\
\text { model }\end{array}$ & Ireland & $\begin{array}{l}\text { Frim resources act as enablers for the } \\
\text { number and value of contracts SMEs } \\
\text { tender for but capabilities are } \\
\text { important for winning contracts }\end{array}$ & $\begin{array}{l}\text { Journal of Small Business } \\
\text { and Enterprise Development }\end{array}$ \\
\hline
\end{tabular}

